\title{
The Country-of-Origin Effect and Its Influence on Consumer Attitudes and Convenience Product Consideration in Durban, South Africa
}

\author{
Andrew R. Kamwendo \\ Department of Marketing \& Retail Management, Durban University of Technology, South Africa, \\ Email:kamwendo5@gmail.com \\ Karen M. Corbishley \\ Department of Marketing \& Retail Management, Durban University of Technology, South Africa, \\ Email: karenc@dut.ac.za \\ Roger B. Mason
}

Department of Marketing \& Retail Management and Institute of systems Science, Durban University of Technology, South Africa

Doi:10.5901/mjss.2014.v5n23p192

\begin{abstract}
County of origin studies have analysed the influence of the origins of a product on consumer attitudes. In the same context, the categorisation both domestic and foreign products into sets for selection possess the potential for research especially within the convenience product category. The literature suggests that the country of origin effect will mean that South African consumers would prefer local over foreign convenience products. Consequently, a cross-sectional descriptive survey was conducted within Durban, South Africa using a research instrument developed from preceding attitudinal studies. 476 useable questionnaires were obtained for the purpose of the study and a presentation of the results obtained was provided. Data was analysed using SPSS 21.0. A Wilcoxon Signed Ranks Test was conducted to measure consideration. The Pearson's chi-square test was used to test for the existence of variances within the responses provided by the respondents. The results showed the existence of a weak positive effect on attitudes and consideration for foreign products among South African citizens. Theoretical and practical implications of the study are presented with the provision of suggestions regarding future research.
\end{abstract}

Keywords: Country-of-Origin, Product consideration, Evoked set, Convenience Products

\section{Introduction}

The consumer decision making process has been the subject of much interest as the major determining factor of consumer's product choices. In accordance with Schiffman and Kanuk (2004) decision making model, consumers' choices are determined by their psychological make-up. Of major interest has been the development of consumer attitudes and how they determine a consumer's product choices. A number of studies have investigated consumer attitudes toward products from different countries-of-origin ( $\mathrm{COO}$ ) which have revealed the country-of-origin as an attribute to product evaluation (Ahmed et al., 2004). Consumers have been known to make use of product information or cue within their product evaluations (Ahmed et al., 2004). A lot of emphasis has been place on the country-of-origin of a product as and a cue of product information. The continued growth of globalisation continues to highlight the need for more country-of-origin studies especially as the amount of product options available to consumers' increases. Consumers have found themselves faced with more product options to choose from, both foreign and domestic. With that, the complexity of each purchase process has increased and in the face of restricted cognitive capacity, only a small amount of alternative choices can remain in the consumers' mind (Shocker et al., 1991). Consumers have been known to use a number of different elements to evaluate product during the pre-selection process. The rationale behind the focus on $\mathrm{COO}$ has been built on the premise that the $\mathrm{COO}$ acts as a predictor of consumer attitudes and consequently product choices (Martín and Cerviño, 2011). Consumer product evaluations during the purchasing process create room for researchers to further understand how consumers develop product choices. As consumers limit their product choices, the establishment of choice sets from which consumers identify their preferred product and/brand choices arouses some 
interest among researchers. Consequently the pre-purchase elements of a consumer's decision making process, which lead up to pre-purchase selection as influenced by a products place of origin, needs further understanding. This is especially true within international marketing where, the preferences of the consumer in different geographical regions have to be considered.

Research has shown that the variances found within a consumers purchasing processes occur as a result of a number of factors where demographics also plays an important role (Wilcock et al., 2004). Consumer attitudes toward products as expressed through demographic variables have been the subject of interest in a number of country-of-origin studies (Wall et al., 1991; Batra et al., 2000; Wilcock et al., 2004). According to Verlegh and Steenkamp (1999) consumer responses to the country-of-origin effect vary in accordance with their individual demographic characteristics. It therefore follows that the relationship between demographic elements and the country-of-origin effect be researched further in order to cater for the population differences within countries.

Although studies have been conducted within Africa on different manifestations of country-of-origin effect, a gap exists within the knowledge surrounding the influence of a products' country-of-origin on the establishment of choice sets. No studies have been conducted linking the country-of-origin effect to product consideration. Very few studies have also catered to low-involvement product categories (Ahmed et al., 2004). As a result, the research questions addressed within the study were:

"what is the nature of consumer attitudes toward foreign convenience products; what effect do they have on the establishment of a consumer's consideration, or evoked set for convenience products; and what is the effect does consumer demographic factors have?"

In order to answer these questions, the following research objectives were set:

- To identify the attitudes of South African consumers toward foreign convenience products

- To determine whether $\mathrm{COO}$ has an effect on convenience product considerations in South Africa

- To identify differences in attitudes toward foreign products according to age, gender, race and education.

\section{Literature}

\subsection{Consideration Construct}

Among a wide range of studies, a common and re-occurring theme is that consumers establish 'choice sets' in any given purchasing instance (Shocker et al., 1991; Simonson and Tversky, 1992). Consumers have been known to restrict themselves to a small group of products which they seriously consider for purchase called a "consideration set" (Laroche et al., 2005). This understanding gives merit to the Funnel Metaphor established by the Mckinsey Institute (2009) (Figure 1). According to Howard (1977:306) the consideration ('evoked') set is "the subset of products that a consumer considers buying out of the set of products that he or she is aware of in a given product class". The term 'consideration' developed as a means of describing a consumer's predisposition to confine their choices to a given set of options. Abougomaah et al. (1987:667) state that the consideration set refers to "those few brands out of all the existing brands in a particular product category given actual purchase consideration by the consumer".

According to Schiffman and Kanuk's (2004) consumer decision making model, a consumer's psychological makeup, which consists of five elements determines a consumer's choice of products. These five elements are also believed to be subjective to each individual as they are influenced by the experiences each particular individual goes through (Foxall, Goldsmith and Brown, 1998). Among these five elements consumer attitudes have been of great interest. According to Wu (2003), of all the psychological factors, consumer attitudes are the most prone to change. As a result, much marketing effort is focused at changing and altering consumer attitudes (Schiffman and Kanuk, 2004). "Attitudes are enduring systems of positive or negative evaluations, emotional feelings, and pro or con action tendencies with respect to social objects" according to Krech, Cruthfield and Ballachy (1962:139, cited by Spence and Townsend, 2008:88). Other authors like Schwarz and Bohner (2001:2), defined attitudes as "an enduring organisation of motivational, emotional, perceptual and cognitive processes to evaluate various objects that are stored in memory". Based on the established definitions of attitudes, it is clear that on this basis, consumer product evaluations are determined by a consumer's attitude. Such evaluations would be influenced by a number of factors such as the strength of the attributes that make up products.

Product attributes find their expression in the form of 'intrinsic' and 'extrinsic' cues, referring to both the built in aspects of the product which make up its physical composition and the non-physical product attributes respectively 
(Liefeld, 1993; Ahmed et al., 1994). According to Court et al (2009) a consumers decision making process can be illustrated in the form of a funnel metaphor (Figure 1). The funnel metaphor tests the strength of a product/brands image as consumer go through their selection process (Court et al., 2009). Ideally, the stronger a products attributes and/ brand image, the greater the likelihood that it will be considered for selection. As a result the strength of other product attributes, such as a products place of origin can also be tested.

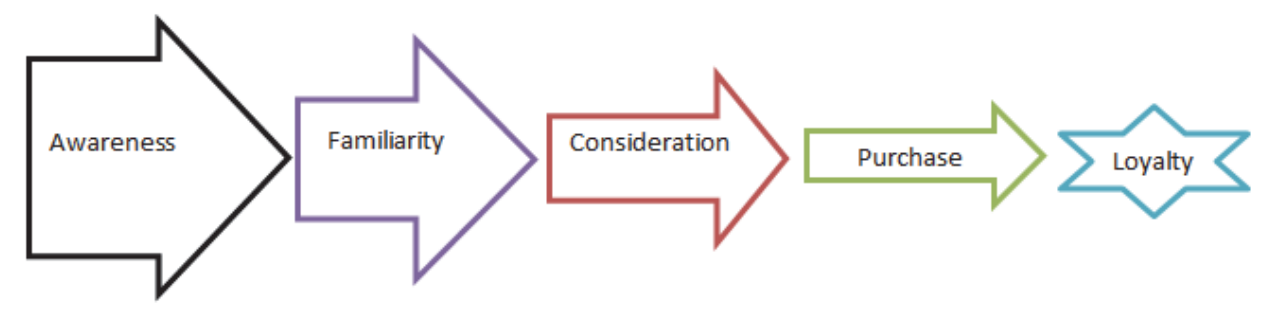

Figure 1: Funnel Metaphor Purchasing Model (Court et al., 2009).

It therefore follows that within the a consumers decision making process the selection pf products is influenced by a consumers attitudes to product attributes which may be based to a large extent on product attributes. Consequently, understanding these elements could be key to determining which products may be considered for selection, that is, which products would fall into the evoked set.

\subsection{Set Size and Formation}

According to Robert and Lattin (1997) the consideration set is believed to be circumstantial and dependent upon each particular purchasing incident, and each customer determines the nature and structure of each consideration set. Consumer evaluation and product consideration have been stated as being closely related constructs (Urban et al., 1993). As a result the factors that influence evaluation would also affect consideration. The structure of each set seems to be affected by the beliefs held by the consumer, the nature of the product and the search process, among other factors (Roberts and Lattin, 1997). The influences of factors such as consumer demographics and psychographic variables have been the subject of a number of studies (e.g., Belonax and Mittelstaedt, 1978). For the purpose of this study the attributes of country-of-origin and product category were identified in order to establish their effect on the formation of a consideration set.

\subsubsection{Country-of-Origin (COO) Effect}

According to Manrai, Lascu and Manrai (1998) COO information in relation to a product's specific attributes is assumed to alter product evaluations, which has come to be known as the "country-of-origin effect". Country-of-origin effect has been defined "as the impact which generalizations and perceptions about a country have on a person's evaluation of the country's products and/or brands" (Lampert and Jaffe, 1996:27). Beyond the COO construct and the perceptions of consumers, it has become apparent that the strength of consumer images of the consideration set needs to be determined. The general understanding is that products from less-developed countries (LDC) have a lower-quality rating as compared to more developed countries (Nes and Bikley, 1993). Studies conducted in the past have positively linked product attributes to the degree of socio-economic growth of a particular nation. The general perception has been that developed countries produce more superior products than LDCs (Ahmed et al., 1994)

Research carried out in LDCs has shown that consumers rate products from their own countries less favourably (Granzin and Olsen, 1998; Jaffe and Carlos, 1995; Okechuku and Onyemah, 1999). De Run (2012) discovered that developing countries exhibited a positive preference for goods from more-developed countries (MDCs) even in the absence of distinct product differences. According to Bilkey and Nes (1982) these evaluations may be subject to change over time. For example Japanese products improved through technological advancements within the country (Cai, 2002).

The COO functions as a signal to product quality whereby, consumers associate place of origin images with brands from that place (Batra et al., 2000; Zeugner-Roth, et al., 2008). Ultimately, based on the country-of-origin effect, a consumer will, therefore, be more willing to purchase a product from a country with a positive country image, especially if the image holds some significance to the product's characteristics (Roth and Romeo, 1992). As a result, it is apparent 
that the country-of-origin is an important factor which needs to be studied further as the impact a products place of origin is may to change over time.

\subsubsection{Product Category}

Studies have been carried out into the variances of each consideration set, relative to specific products (e.g., Narayana and Markin, 1975; Hauser and Wernerfelt, 1990). Specific product categories seem to be related to specific places of origin (Cordell, 1991; Roth and Romeo, 1992). Some countries have a good reputation for producing particular products, for example, the Chinese for silk, the French for wine and perfume, the Germans for automotive machinery, and the Italians for clothing (Tse and Gorn, 1993; Samiee, 1994; Bhaskaran and Sukumaran, 2007). Some authors have even stated that the significance of the place of origin appeared greater for technically complex products than for simpler products (Eroglu and Machleit, 1988). However, variances based on the product dimensions have been found within this line of thought (Leonidou et al., 1999).

Studies reveal that the perceived effect of a country's economic development was believed to be the same for all the product categories (Manrai et al., 1998). Other studies have since revealed that a bias of preference against developing country products seems to rise in the luxury product class (Manrai et al., 1998). Cordell $(1991,1992)$ makes the assertion that increases in the level of perceived risk will cause consumers to reject products from developing countries. Furthermore, products in the luxury markets suffer more rejection than products within other categories and these findings refer to studies conducted in developed countries.

Inconsistencies exist in the relationships between respondents' cultures and product categories (Giraldi and Ikeda, 2009). These variances seem to cover all product categories (shopping, specialty and convenience products). However, even though variances have been identified, a positive correlation between product durability, specialty products and the place of origin exists (Tse and Gorn, 1992; Zhang, 1996).

A lot of emphasis has been placed on understanding the influences of $\mathrm{COO}$ on high involvement product evaluations. According to Hanzaee and Khosrozadeh (2011) a study carried out by Petty, Cacioppo and David (1983) discovered that high product involvement has a higher correlation with consumer product attitudes and ultimately purchasing intentions. High involvement products are described as "products which are complex or expensive or new and need consumers to spend time in evaluating and purchasing" (Dahlem, Lange and Smith, 2010:295). Past research has focused primarily on high involvement product evaluations and their correlation to COO effect (De Run et al., 2012). Findings have shown that $\mathrm{COO}$ affects consumers' product evaluations but not in all cases (De Run et al., 2012). Low involvement products are products which entail a very short search process. They are typically lower in cost and are comprised of products such as food staples (Ahmed et al., 2004; Lin and Chen, 2006; Phau and Suntornnond, 2006). The purchasing choice is made almost instantaneously. The consumer is hardly concerned about not purchasing the best product (Kraetke, 2000). Although some research results indicate that the impact of COO on product involvement does matter (Ahmed et al., 2004), it is unclear as to what the full effect may be and whether its impact on product evaluation has been overlooked in other countries.

\subsubsection{Conclusion}

Research has shown that COO information seems to supersede other product cues (Tse and Gorn, 1993). Although the formulation of the consideration set is still vague, $\mathrm{COO}$ information is believed to alter the consideration of brands. Based on COO research, it is assumed that brands from developed countries are likely to receive favourable consideration among consumers while other products are rejected because of the association between consideration and evaluation (Manrai et al., 1998).

Studies have also revealed that products belonging to different categories require varying levels of consumer involvement (Hanzaee and Khosrozadeh, 2011). Certain product categories such as specialty products are regarded as high involvement products requiring a lot of consumer participation within the purchase process (Dahlen, Lange and Smith, 2010:295). Low involvement products are regarded as products that require little information search (Dahlen, Lange and Smith, 2010:295). Much focus has been placed on understanding the consideration of high involvement products (Hanzaee and Khosrozadeh, 2011:628).

As the COO information has been known to supersede other product attributes the following hypothesis was developed:

H1: The COO effect causes favourable consideration of foreign convenience products among South Africans within Durban. 


\subsection{Measuring Consideration}

Due to the link between product evaluation and consideration, product consideration is believed to result in the formation of perceptions, attitude and opinions about a product (Hulland, 1999). A study by Carter (2009) used a 7-point Likert scale to evaluate products from different countries. The questions required respondents to indicate levels of agreement with regard to each given question. Respondents were required to evaluate products under a number of guidelines such as workmanship, design, durability and value for money, which could also be used to determine possible consideration. Numerous studies have used five point scales to measure consumer attitudes and as a measure of purchasing intent (Batra and Ray, 1986; MacKenzie et al., 1986; Spears and Singh, 2004). Within the context of organisational attitude, a study by Lowe et al. (2003) of employee attitudes, using a five point scale to assess employee attitudes, shows how attitude measurement can be linked to other constructs acting as a precursor to behaviour. Thus, product consideration measurement can be inferred by using product evaluation criteria through the use of five point scales.

\section{Methodology}

The study was in the form of a descriptive, cross-sectional survey investigating the relationships between the COO effect and product consideration, as well as the effect various demographic characteristics have on such a relationship. According to Churchill and lacobucci (2010) descriptive research identifies the frequency of something occurring or the relationship between variables, which is the objective of the study.

\subsection{Sampling}

The population of this study comprised approximately 65000 students and staff members from two universities within the greater Durban, South Africa area, viz. Durban University of Technology and University of KwaZulu-Natal. The greater the size of the sample the more reliable the research findings, and Roscoe (1975, cited by Sekaran and Bougie, 2010) emphasizes that an appropriate sample size is between 30 and 500 respondents, and that for a population size of 75000 and 1000000 the sample size should be between 382 and 384. Purposive sampling was used to select the universities for their ability to provide the full range of the demographics. The study made use of quota sampling within the universities. Quota sampling criteria included the demographic characteristics of age, gender, education and ethnicity (see Table 1). Convenience sampling was used to select individual respondents. Seven or eight respondents were selected for each quota cell. A final useable sample of 476 completed questionnaires was obtained.

Table 1: Desired Sample Size

\begin{tabular}{|c|c|c|c|c|c|c|c|c|c|c|}
\hline \multirow{2}{*}{\multicolumn{2}{|c|}{$\begin{array}{c}\text { Age } \\
\text { Highest } \\
\text { qualific Ethnicity }\end{array}$}} & \multicolumn{4}{|c|}{ Young $(18-40)$} & \multicolumn{4}{|c|}{ Old $(41-65)$} & \multirow{2}{*}{ Total } \\
\hline & & Matric & Diploma & Degree & Postgrad & Matric & Diploma & Degree & Postgrad & \\
\hline \multirow{2}{*}{ Black } & Male & 7 & 7 & 7 & 7 & 7 & 7 & 7 & 7 & 56 \\
\hline & Female & 8 & 8 & 8 & 8 & 8 & 8 & 8 & 8 & 64 \\
\hline \multirow{2}{*}{ White } & Male & 7 & 7 & 7 & 7 & 7 & 7 & 7 & 7 & 56 \\
\hline & Female & 8 & 8 & 8 & 8 & 8 & 8 & 8 & 8 & 64 \\
\hline \multirow{2}{*}{ Coloured } & Male & 7 & 7 & 7 & 7 & 7 & 7 & 7 & 7 & 56 \\
\hline & Female & 8 & 8 & 8 & 8 & 8 & 8 & 8 & 8 & 64 \\
\hline \multirow{2}{*}{ Indian } & Male & 7 & 7 & 7 & 7 & 7 & 7 & 7 & 7 & 56 \\
\hline & Female & 8 & 8 & 8 & 8 & 8 & 8 & 8 & 8 & 64 \\
\hline \multicolumn{2}{|c|}{ Total } & 60 & 60 & 60 & 60 & 60 & 60 & 60 & 60 & 480 \\
\hline
\end{tabular}

\subsection{Data Collection}

A self-completion questionnaire was utilized to collect data. The questionnaire was divided into two sections which comprised product consideration questions (Table 2) and questions about participant's demographics. The questions were adapted and developed from existing scales for willingness to buy, consumer attitude towards products and product evaluation questions (Carter, 2009). Product consideration questions were Likert scaled with labelled response categories ranging from $1=$ strongly agree to $5=$ strongly disagree. 
Questionnaires were administered to students from two universities for completion via classroom intercept while questionnaires were emailed to staff members from the two universities for completion. Classrooms, in which questionnaires were to be administered, were chosen based on the researcher's convenience until the quota was filled. The questionnaires were administered by the researcher in the presence of an appointed university representative. Respondents were required to drop completed questionnaires into a sealed box to ensure confidentiality and anonymity.

\subsection{Data analysis}

Descriptive statistical methods were utilised to summarise the data and the appropriate inferential statistics were used to test the statistical significance of the findings. A Wilcoxon Signed Ranks Test was conducted to measure consideration. The Pearson's chi-square test was used to test for the existence of variances within the responses provided by the respondents. The data was analysed using the Statistical Package for Social Sciences (SPSS version 21.0).

\subsection{Reliability}

The success of any given study is dependent upon the research's reliability and validity. According to Welman et al. (2005), an internal consistency method can be employed to determine the reliability of a measuring instrument. The questionnaire scored a value of 0.644 , which is slightly lower than the required standard of 0.7 (Andrew et al., 2011: 202). The primary reason for this score is that the construct is newly developed and would require further testing. Improvements have been noted since it was piloted.

\subsection{Validity}

Factor analysis is a tool that allows researchers to explore underlying structures of an instrument or set of data (Metler and Vannatta, 2002). It is a tool within which a set of questions within a survey can be reduced or subdivided into a smaller set of hypothetical factors (Moonsamy and Singh, 2012). Factor analysis was used to determine whether the instrument questions measured the same item (see Table 2).

Table 2: Product Consideration (Questions)

\begin{tabular}{|l|c|c|c|}
\hline & \multicolumn{2}{|c|}{ Component } \\
\cline { 2 - 4 } & 1 & 2 & 3 \\
\hline 2. Foreign products are cheaper than domestic products & -.171 & .777 & .161 \\
\hline 3. Foreign products last long & .155 & .075 & .892 \\
\hline 4. Foreign product are of great value for money & .646 & .017 & -.116 \\
\hline 5. Foreign products are generally of lower quality compared similar domestic products & -.435 & .615 & .016 \\
\hline 6. I am happy with the foreign products I have purchased & .761 & -.130 & .168 \\
\hline 7. I am likely to recommend foreign products to others & .703 & -.215 & .197 \\
\hline 8. I reject products I have a negative attitude towards & .361 & .597 & -.374 \\
\hline
\end{tabular}

Rotation Method: Varimax with Kaiser Normalization. a. Rotation converged in 5 iterations.

The method employed in the extraction of elements was the principal component analysis and the Varimax with Kaiser Normalization as the main method of rotation. As a result, items found to be 0.5 or more imply an effective measurement along the various components. The variables that constituted the questionnaire (Table 2) split along three sub-themes. These sections are characterised by questions that induced positive and negative considerations (subdivision 1 and 2, respectively), while the last question (subdivision 3) did not induce either positive or negative consideration but rather indifference.

\section{Results}

\subsection{Sample description}

For the purpose of the study the desired sample size was 480 participants. Only 476 participants provided usable responses to questions asked within the research instrument. The sample distribution is illustrated within Table 3. 
Table 3: Sample distribution

\begin{tabular}{|c|c|c|c|}
\hline Demographic variables & Characteristics & Frequency & Percentage \\
\hline \multirow{4}{*}{ Level of education } & Primary & 3 &, 6 \\
\cline { 2 - 4 } & High School & 221 & 46,4 \\
\cline { 2 - 4 } & Diploma & 85 & 17,9 \\
\cline { 2 - 4 } & Degree & 111 & 23,3 \\
\cline { 2 - 4 } & Postgraduate & 56 & 11,8 \\
\hline \multirow{4}{*}{ Race } & Black & 314 & 66,0 \\
\cline { 2 - 4 } & White & 50 & 10,5 \\
\cline { 2 - 4 } & Coloured & 54 & 11,3 \\
\cline { 2 - 4 } & Indian & 58 & 12,2 \\
\hline \multirow{4}{*}{ Age group } & $18-20$ & 146 & 30,7 \\
\cline { 2 - 4 } & $21-35$ & 258 & 54,2 \\
\cline { 2 - 4 } & $36-50$ & 56 & 11,8 \\
\cline { 2 - 4 } & $51-65$ & 16 & 3,4 \\
\hline \multirow{3}{*}{ Gender } & Male & 250 & 52,5 \\
\hline Total & Female & 226 & 47,5 \\
\hline & & 476 & 100,0 \\
\hline
\end{tabular}

\subsection{Descriptive statistical findings}

Eight product consideration questions were constructed. A summary of the results obtained is presented in Figure 2 showing collapsed results of the five point Likert scale into three categories, disagree, undecided and agree. In order to identify consumer attitudes towards foreign product purchase, emphasis was placed on the level of agreement and disagreement and not on the undecided responses provided. Form the level agreement and disagreement positive or negative attitudes would be obtained from participants responses.

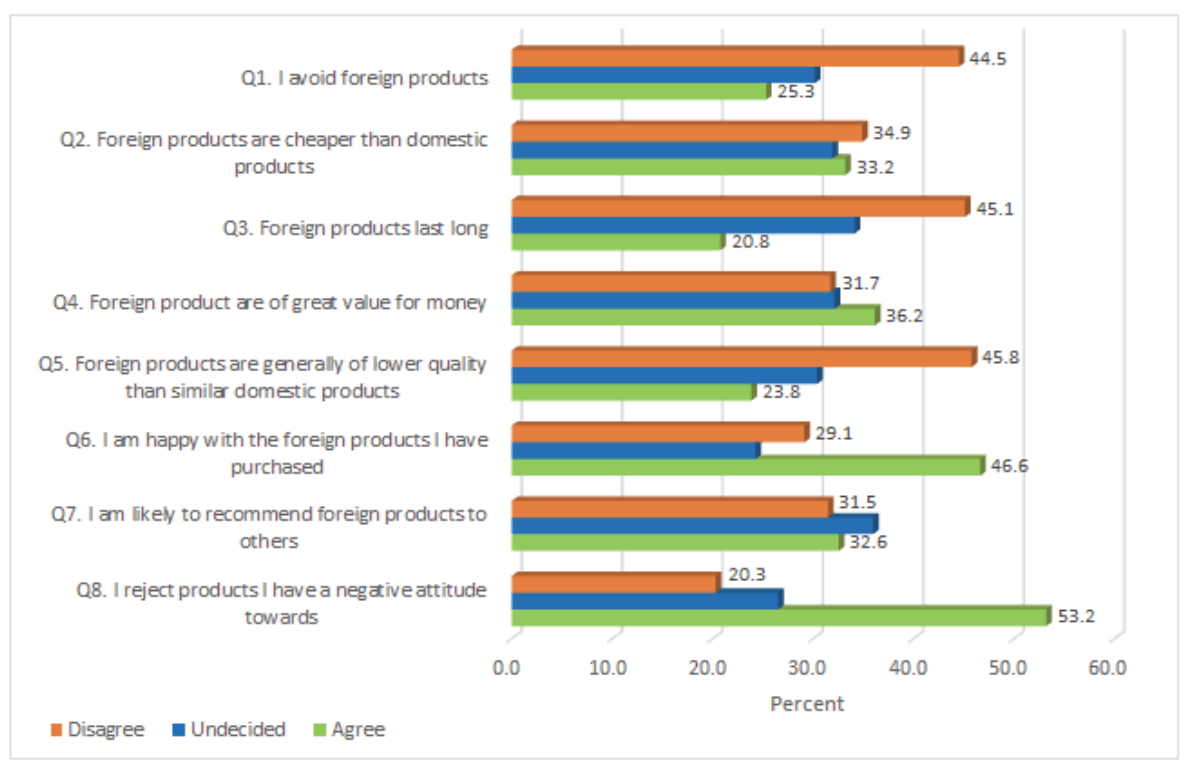

Figure 2: Collapsed Product Consideration Scores

As illustrated in Figure 2 respondents only agreed with three statements, "I am happy with foreign products I have purchased," "Foreign products are of great value for money" and "I reject products I have a negative attitude towards". Although there are more respondents who agreed than disagreed, the difference is relatively small. For example, the levels of agreement and disagreement to the statement, "I am likely to recommend foreign products," were $32.6 \%$ and $31.5 \%$, respectively. The largest margin between agreement and disagreement was for the statement "I reject products I 
have a negative attitude towards" with $53.2 \%$ in agreement and $20.3 \%$ in disagreement. For the remaining statements, there are more respondents who disagreed (more than those that agreed) (Figure 2).

Results show a general dislike for foreign products, which may be emanating from the idea that foreign products are made poorly and do not last long. Responses also showed that the majority of participants believe foreign products are of poor quality. The majority of participants also display the belief that foreign products are of great value. Inconsistencies arose as responses showed that the majority of participants were happy with the foreign products they had come across and that they would recommend them to other consumers. As illustrated in Figure 2, there were more participants who were undecided (31.5\% agreed compared to $32.6 \%$ who disagreed) about the decision to recommend a foreign product.

Due to the conditions of normality not being met (Kolmogorov Smirnov p-value $<0.001$ ) a Wilcoxon Signed Ranks Test (Table 4) was used. The Wilcoxon test compares the actual median score against the expected standard median value for the best case scenario (for agreement).

Table 4: Wilcoxon Signed Ranks Test

\begin{tabular}{|c|c|c|c|c|}
\hline \multicolumn{2}{|l|}{ Ranks } & $\mathrm{N}$ & Mean Rank & Sum of Ranks \\
\hline \multirow{4}{*}{ Brand Standard - Brand Average } & Negative Ranks & $474^{a}$ & 237.50 & 112575.00 \\
\hline & Positive Ranks & $0^{b}$ & .00 & .00 \\
\hline & Ties & $0^{c}$ & & \\
\hline & Total & 474 & & \\
\hline \multicolumn{5}{|l|}{ a. Brand Standard < Brand Average } \\
\hline \multicolumn{5}{|l|}{ b. Brand Standard > Brand Average } \\
\hline c. Brand Standard = Brand Average & & & & \\
\hline
\end{tabular}

\begin{tabular}{|l|c|}
\hline \multicolumn{2}{|c|}{ Test Statistics $^{\mathrm{a}}$} \\
\hline $\mathrm{Z}$ & Brand Standard - Brand Average \\
\hline \multicolumn{1}{|c|}{ Asymp. Sig. (2-tailed) } & $-18.883^{\mathrm{b}}$ \\
\hline a. Wilcoxon Signed Ranks Test & .000 \\
\hline b. Based on positive ranks. \\
\hline
\end{tabular}

The responses put forward by the research participant's show that the average percentage of agreement for all the statements was $34.0 \%$. The average percentage of disagreement for all statements within the questionnaire was $35.4 \%$ while the average percentage of undecided responses was $30.7 \%$ (Table 5). Based on the responses put forward it is clear that the majority of responses did not agree with the statements displaying a negative attitude towards foreign products. Consequently, on average respondents displayed relatively similar attitudes towards toward foreign products.

Table 5: Collapsed Response Frequency Distribution

\begin{tabular}{|l|c|c|c|}
\hline & Agree & Undecided & Disagree \\
\hline I reject brands I have a negative attitude towards & 53,2 & 26,5 & 20,3 \\
\hline Likely to recommend foreign brands & 32,6 & 36,0 & 31,5 \\
\hline Happy with foreign brand & 46,6 & 24,3 & 29,1 \\
\hline Foreign brand are of low quality & 23,8 & 30,4 & 45,8 \\
\hline Foreign product are great value & 36,2 & 32,1 & 31,7 \\
\hline Foreign last long & 20,8 & 34,1 & 45,1 \\
\hline Foreign products are cheap & 33,2 & 31,9 & 34,9 \\
\hline I avoid foreign products & 25,3 & 30,2 & 44,5 \\
\hline Average & 34.0 & 30.7 & 35.4 \\
\hline
\end{tabular}

In order to determine whether the differences in responses put forward were significant, chi-square tests were done by variable (statement). All the $p$-values are less than 0.05 , implying that the scoring patterns show significant differences (Table 6). The differences between agreement and disagreement were significant and, again, it must also be noted that the category of "Undecided" contributed to the $p$-value. 
Table 6: Chi square test results

\begin{tabular}{|c|c|c|c|c|c|c|c|c|}
\hline & $\begin{array}{c}\text { I avoid } \\
\text { foreign } \\
\text { products }\end{array}$ & $\begin{array}{c}\text { Foreign } \\
\text { products are } \\
\text { cheap }\end{array}$ & $\begin{array}{c}\text { Foreign } \\
\text { product last } \\
\text { long }\end{array}$ & $\begin{array}{c}\text { Foreign } \\
\text { products are } \\
\text { great value }\end{array}$ & $\begin{array}{c}\text { Foreign } \\
\text { products are of } \\
\text { low quality }\end{array}$ & $\begin{array}{c}\text { Happy with } \\
\text { foreign } \\
\text { products }\end{array}$ & $\begin{array}{c}\text { Likely to } \\
\text { recommend } \\
\text { foreign products }\end{array}$ & $\begin{array}{c}\text { I reject products I } \\
\text { have a negative } \\
\text { attitude towards }\end{array}$ \\
\hline Chi Sq & 55.473 & 45.636 & 99.186 & 55.573 & 63.532 & 34.608 & 87.745 & 83.944 \\
\hline $\mathrm{df}$ & 4 & 4 & 4 & 4 & 4 & 4 & 4 & 4 \\
\hline $\mathrm{Sig}$. & .000 & .000 & .000 & .000 & .000 & .000 & .000 & .000 \\
\hline
\end{tabular}

\subsection{Bi-variate analysis}

The chi-square test was also performed to establish the existence or non-existence of statistically significant relationships between the various demographic variables and the product consideration variable (Vaughan, 2001). From the statistical test, a $p$-value is generated, whereby $p<0.05$ indicates of a level of difference that is statistically significant. Table 7 summarises the results from the chi-square tests.

Table 7: Pearson Chi-Square Tests

\begin{tabular}{|l|c|c|c|c|}
\hline & Age group & Gender & Ethnicity & Level of education \\
\hline 1. I avoid foreign products & 0.783 & .128 & .398 & 0.916 \\
\hline 2. Foreign products are cheaper than domestic products & 0.433 & .730 & .095 & 0.754 \\
\hline 3. Foreign last long & 0.673 & .524 & .256 & 0.213 \\
\hline 4. Foreign product are great value for money & $.042^{*}$ & $.040^{*}$ & .064 & 0.521 \\
\hline 5. Foreign products are of lower quality than domestics products & 0.622 & $.006^{*}$ & $.035^{*}$ & 0.351 \\
\hline 6. I am happy with the foreign products I have purchased & 0.185 & .616 & $.000^{*}$ & 0.127 \\
\hline 7.I am likely to recommend foreign products to others & 0.437 & .271 & $.002^{*}$ & 0.733 \\
\hline 8. I reject products I have a negative attitude towards & 0.555 & .288 & .700 & 0.432 \\
\hline
\end{tabular}

The results from the chi-square test support the existence of a number of significant relationships between respondents' biographical data and some of the research statements. Ethnicity showed significant relationships with the following statements: "Foreign products are of lower quality than domestic products", "I am happy with foreign products I have purchased" and "I am likely to recommend foreign products to others" ( $p=0.035, p=0.00$ and $p=0.002$, respectively). The statement "Foreign products are of great value for money" has a significant association with the following biographical data "Age group" and "Gender". This means that the belief that foreign products are of great value is influenced by both a respondent's age group and gender ( $p=0.42$ and $p=0.4$ respectively). Respondents' gender also shows a significant relationship to the belief that "Foreign products are of lower quality the domestic products" $(p=0.006)$ together with the respondents' ethnicity $(p=0.035)$. The mean responses as well as the total mean responses provided for each question, based on the demographic characteristics, are provided in the Appendix, thereby summarising how the research participants responded to each question.

\section{Discussion}

The Wilcoxon rank test revealed a KS p-value $<0.001$, indicating that a different within the overall responses put forward by respondents. The results of the study show that on average, more respondents disagreed with the research statements. The results also show a slight difference within the average mean score which showed 34.0 were in agreement and 35.4 in disagreement. The average means show that $30.7 \%$ of respondent were undecided and were relatively indifferent to the research questions. These slight differences in attitudes towards foreign convenience products can be attributed to South Africa's long history with foreign products which may make it difficult for consumers to separate foreign product from domestic products (De Run et al., 2012). This may also be attributed to the levels of consumer involvement required within the product category which do not require consumers to search out a products origin. Consequently, greater variance is likely to be witnessed within other product categories. Nonetheless, research has shown that the $\mathrm{COO}$ effect does affect the product purchase considerations of low involvement products though the effect may be fairly weak (Ahmed et al., 2004).

The Pearson's chi-square test also revealed the existence of significant relationships between consumer 
demographics and the following items:

4. Foreign convenience products are usually of great value for money;

5. Foreign convenience products are generally of lower quality than similar local products;

6. I am happy with the foreign convenience products I have purchased; and

7. I am likely to recommend foreign convenience products to others.

The results illustrate the existence of significant relationships between respondents' age and Item 4 . That is, mean scores show that participants generally agreed with the statement. An association was also discovered between Item 4 and the respondent's gender. Associations were also discovered between respondent's ethnicity and gender and Item 5 . Their mean scores show that participants generally disagreed with this statement. Respondent's ethnicity showed other associations with Item 6 and Item 7 to which participants generally agreed with both statements.

The results also show that respondents only disagreed with statements that induced negative attitudes within the respondent mind. Respondents agreed with statements that induced positive attitudes within the respondents mind. Overall mean scores for each of the consideration questions show that participants disagreed with four and agreed with four. Participants stated that foreign products were of great value, that they were happy with the products that they had come across and that they would recommend these products. This positive attitude could be the result of a long history of foreign product consumption and favourable rating of imported products, specifically from MDCs (De Run et al., 2012). On the basis of these results, the $\mathrm{H} 1$ hypothesis was accepted.

Although results show a favourable consideration towards foreign products, the given product category (convenience products) requires little involvement by the consumer. As a result varied results may be witnessed for other product categories. For more involved products, consumers may display an even more positive attitude and greater consideration for foreign products (Roth and Romeo, 1992; Giraldi and Ikeda, 2009).

\section{Academic Implications}

The study is a pioneering endeavour within the field of product selection in South Africa. The study looks at the purchasing process and identifies some of the factors that precede product purchase. The study is the first in South Africa to look at the establishment of choice sets. The study takes a further look at the elements that affect pre-purchase behaviour by analysing the developments that lead up to the establishment of a consumer's pool of selection. The study explores the depth of the influence of the $\mathrm{COO}$ effect on the establishment of consumer choice sets within a product category that has not seen much research. The findings therefore helps improve understanding into the elements that affect consumer decision making in South Africa as impacted by a products place of origin. The study introduces the idea of the establishment of a product consideration measuring instrument.

\section{Managerial Implications}

Understanding the influence of a products' place of origin enables companies to communicate their products and services better. International marketing firms may choose to highlight the place of origin of their products in order to further differentiate them from those of their competitors, especially within a low involvement category like convenience product were product differentiation may be difficult. Depending on how positive the COO image is marketing firms may choose to highlight the product's place of origin as some consideration is given to a products place of origin. South African consumers continue to place some consideration to the place of origin of a product.

\section{Limitations}

The applicability of the results of the study is limited, due to the inadequacies of the research instrument. The instrument did not undergo in-depth testing. Another limitation of the study is that, no specific countries were identified. The study was conducted as a generalisation of the $\mathrm{COO}$ effect without identifying any specific country and does not take into account the variance between countries and between regions. The study cannot be generalised due to the fact that only one specific product category was investigated. Variances are likely to exist between products of different categories. As a result the $\mathrm{COO}$ effect is likely to be higher or lower depending on the given category.

\section{Directions for Future Studies}

Country of origin studies should investigate the relationships between South African consumers and country specific 
products. Researchers should investigate the attitudes that South African consumers have towards products from different countries. These relationships should also be analysed at regional levels in order to determine whether specific regions such as Europe, Asia or the Americas, induce collective attitudes among consumers. Further studies should focus on the development of a research instrument to more reliably measure product consideration. The development of a proven instrument would help improve the application of the research results. Future studies should also investigate changes within country-of-origin images and their influences on South African consumers as well as other developing economies.

\section{Conclusion}

This study set out to identify the role that consumer attitudes towards foreign products play in determining a consumer's consideration, or evoked, set for convenience products, and to what extent this influence is affected by demographic factors. The results have shown that a moderately positive attitude towards foreign products exists, which means that foreign products would be included in a consumer's consideration set. The study also assessed the extent to which attitude to foreign convenience products is influenced by demographic factors.

\section{References}

Abougomaah, N. H., Schlacter, J. L. \& Gaidis, W. (1987). "Elimination and choice phases in evoked set formation". Journal of Consumer Marketing, 4 (4), 67-72

Ahmed, Z. U., Johnson J. P., Yang, X., Fatt, C. K., Teng, H. S. \& Boon, L. C. (2004). "Does country of origin matter for low-involvement products?" International Marketing Review, 21 (1), 102-120.

Andrew, D. P. S., Pedersen, P. M. \& MacEvoy, C. D. (2011). Research methods and design in sport management. Champaign, IL: Human Kinetics.

Batra, R. \& Ray, M. L. (1986). "Situational effects of advertising repetition: The moderating influence of motivation, ability, and opportunity to respond". Journal of Consumer Research, $432-445$.

Batra, R., Ramaswamy, V., Alden, D. L., Steenkamp, J. B. E., \& Ramachander, S. (2000). "Effects of brand local and nonlocal origin on consumer attitudes in developing countries". Journal of Consumer Psychology, 9 (2), 83-95.

Belonax, J. A. \& Mittelstaedt, R. A. (1978). "Evoked set size as a function of number of choice criterion and information variability". Advances in Consumer Research, 5, 48-51.

Bhaskaran, S. \& Sukumaran, N. (2007). "Contextual and methodological issues in COO studies". Marketing Intelligence and Planning, 25 (1), 66-81.

Cai, Y. (2002). Country-of-origin effects on consumers' willingness to buy foreign products: An Experiment in Consumer Decision. Unpublished masters' dissertation. University of Georgia.

Carter, L. L. Jr. (2009). Consumer receptivity of foreign products: The roles of country-of-origin image, consumer ethnocentrism and animosity. Unpublished doctoral dissertation. Old Dominion University.

Churchill, D. A. \& lacobucci, D. (2010). Market Research. Methodological Foundations, $2^{\text {nd }}$ ed. Ohio: Mason.

Cordell, V. (1991). "Competitive context and price as moderators of country of origin preferences". Journal of the Academy of Marketing Science, Vol. 19 No. 2, 123-8.

Cordell, V. (1992). "Effects of consumer preferences for foreign sourced products". Journal of International Business Studies, 23 (2), $251-69$.

Court, D., Elzinga, D., Mulder, S. \& Vertvik, O. J. (2009). 'The Consumer Decision Journey', McKinsey Quarterly, viewed 29 November 2013, from https://www.mckinsey.com/insights/marketing_sales/the_consumer_decision_journey.

Dahlen, M., Lange, F. \& Smith, T. (2010). Marketing Communications: A brand narrative approach. Wiley. com.

De Run, E. C. \& Chan, A. W. S., and Khalique, M. (2012). "Attitudinal and behavioural response to country of origin cues for low involvement product". International Journal of Research Studies in Management, 1 (2), 3-14.

Eroglu, S. A. \& Machleit, K. A. (1988). "Effects of individual and product-specific variables on utilising country of origin as a product quality cue". International Marketing Review, 6 (6), 27-41.

Foxall, G. R., Goldsmith, R. E. \& Brown, S. (1998). Consumer psychology for marketing, 1. Cengage Learning EMEA: 3-8.

Granzin, K. L. \& Olsen, J. E. (1998). "Americans' choice of domestic over foreign products: A matter of helping behaviour?" Journal of Business Research, 43 (1), 39-54.

Giraldi, J. M. D. \& Ikeda, A. A. (2009). "Personal values and the country-of-origin effect: the moderating role of consumers' demographics". International Journal of Consumer Studies, 33 (3), 309.

Hanzaee, K. H. \& Khosrozadeh, S. (2011). "The effect of the country-of-origin image, product knowledge and product involvement on information search and purchase intention". Middle-East Journal of Scientific Research, 8 (3), 625-636.

Hauser, J. R. \& Birger, W. (1990). "An evaluation cost model of evoked sets". Journal of Consumer Research, 16 (4), 393-408.

Howard, J. A.(1977). Consumer Behaviour: Application of Theory. New York: McGraw-Hill.

Howard, J. A. \& Sheth, J. (1969). The Theory of Buyer Behaviour: New York: Wiley.

Hulland, J. S. (1999). "The effects of country-of-brand and brand name on product evaluation and consideration". Journal of International 
Consumer Marketing, 11 (1), 23-40.

Jaffe, E. D. \& Carlos, R. M. (1995). "Mexican consumer attitudes towards domestic and foreign made products". Journal of International Consumer Marketing, 7 (3), 7-27.

Kraetke, V. (2000). Analysis of a tooth paste brand: A low involvement good. Unpublished term paper. University of Auckland, Auckland.

Lampert, S. I. \& Jaffe, E. D. (1996). "Country of origin effects of international market entry". Journal of Global Marketing, 10 (2), $27-52$.

Laroche, M., Papadopoulos, N., Heslop, L. \& Mourali, M. (2005). "The influence of country image structure on consumer evaluations of foreign products". International Marketing Review, 22 (1), 96-115.

Lehmann, D. R. \& Pan, Y. (1994). "Context effects, new brand entry, and consideration sets". Journal of Marketing Research, 31 (3), $364-374$

Leonidou, L. C., Hadjimarcou, J., Kaleka, A. \& Stamenova, G. T. (1999). "Bulgarian consumer's perceptions of products made in Asia Pacific". International Marketing Review, 16 (2), 126-142.

Liefeld, J. (1993). Experiments on country-of-origin effects: review and meta-analysis of effect size. In: Papadopoulos, C and Heslop, L (Eds.). Product-country images: Impact and role in international marketing. New York, International Business Press, 117-156.

Lin, L. Y. \& Chen, C. H. (2006). "The influence of the country-of-origin image, product knowledge and product involvement on consumer purchase decisions: An empirical study of insurance and catering services in Taiwan". Journal of Consumer Marketing, 23 (3), $145-$ 155.

Lowe, G. S., Schellenberg, G. \& Shannon, H. S. (2003). "Correlates of Employees' Perceptions of a Healthy Work Environment". American Journal of Health Promotion, 17 (6), 390-399.

Manrai, L. A., Lascub, D. \& Manrai, A. K. (1998)." Interactive effects of country of origin and product category on product evaluations". International Business Review, 7, 591-615.

MacKenzie, S. B., Lutz, R. J. \& Belch, G. E. (1986). "The role of attitude toward the ad as a mediator of advertising effectiveness: A test of competing explanations". Journal of Marketing Research, 23 (2), 130-143.

Martín, O. M. \& Cerviño, J. (2011). "Toward an integrative framework of brand country of origin recognition determinants: A cross-classified hierarchical model". International Marketing Review, 28 (6), 530-558.

Narayana, C. L. \& Markin, R. J. (1975). "Consumer behavior and product performance: An alternative conceptualization". Journal of Marketing, 39, 1-6.

Nes, E. \& Bilkey, W. J. (1993). A multi-cue test of country-of-origin theory. In: Papadopoulos, N. and Heslop, L. A. (Eds.). Product-country images. New York: International Business.

Okechuku, C. and Onyemah, V. (1999). "Nigerian consumer attitudes toward foreign and domestic products". Journal of International Business Studies, 30 (3), 611-22.

Parameswaran, R. \& Pisharodi, R. M. (1994). "Facets of country of origin image: An empirical assessment". Journal of Advertising, 23 (1), $43-61$.

Phau, I. \& Prendergast, G. (2000). "Conceptualizing the country of origin of brand". Journal of Marketing Communications, 6 (3), $159-170$.

Roberts, J. H. \& Lattin, J. M. (1997). "Consideration: Review of research and prospects for future insights". Journal of Marketing Research, 34 (3), 406-410.

Roth, M. S. \& Romeo, J. B. 1992. "Matching product category and country image perceptions: A framework for managing country-of-origin effects". Journal of International Business Studies, 23 (3), 477-497.

Samiee, S. 1994. "Customer evaluation of products in a global market". Journal of International Business Studies, 25 (3), $579-604$.

Schiffman, L. G. \& Kanuk, L. L. (2004). Consumer behavior, $8^{\text {th }}$ ed. New Jersey: Pearson Education, Inc.

Schwarz, N. \& Bohner, G. (2001). The construction of attitudes. manuscript of a chapter in A. Tesser and N. Schwarz (Eds.). Intrapersonal processes (Blackwell Handbook of Social Psychology), Oxford, UK: Blackwell, 436-457.

Sekaran, U. \& Bougie, R. 2010. Research methods for business: A skill building approach, $5^{\text {th }}$ ed. Chichester: Wiley.

Shocker, A. D., Ben-Akiva, M., Boccara, B. \& Nedungadi. 1991. "Consideration set influences on consumer decision-making and choices: Issues models and suggestions". Marketing Letters, 2 (3), 181-197.

Simonson, I. \& Tversky, A. 1992. "Choice in context: tradeoff contrast and extremeness aversion". Journal of Marketing Research, 29, 281295.

Spears, N. \& Singh, S. N. (2004). "Measuring attitude toward the brand and purchase intentions". Journal of Current Issues and Research in Advertising, 26 (2), 53-66.

Spence, A. and E. Townsend. (2008). "Spontaneous evaluations: Similarities and differences between the affect heuristic and implicit attitudes". Cognition and Emotion, 22 (1), 83-93.

Tse, D. K. \& Gorn, G. J. 1993. "An experiment on the salience of country of origin in the era of global brands". Journal of International Marketing, 1 (1), 57-76.

Urban, G. L., Hulland, J. S. \& Weinberg, B. D. 1993. "Premarket forecasting for new consumer durable goods: Modeling categorization, elimination, and consideration phenomena". Journal of Marketing, 57 (2), 47-63.

Vaughan, L. 2001. Statistical methods for the information professional: A practical, painless approach to understanding, using, and interpreting statistics, (Vol. 367). Information Today, Inc.

Wall, M., Liefeld, J. \& Heslop, L. A. 1991. "Impact of country-of-origin cues on consumer judgments in multi-cue situations: A covariance analysis". Journal of the Academy of marketing Science, 19 (2), 105-113.

Wilcock, A., Pun, M., Khanonax, J. \& Aung, M. (2004). "Consumer attitudes, knowledge and behaviour: A review of food safety issues". Trends in Food Science and Technology, 15, 56-66.

Zhang, Y. (1996). "Chinese consumers' evaluation of foreign product: the influence of culture, product types and product presentation format". European Journal of Marketing, 30 (12), 50-68. 
Appendix: Mean responses per demographic variable per question

\begin{tabular}{|c|c|c|c|c|c|c|c|c|c|}
\hline & & $\begin{array}{l}\text { I avoid } \\
\text { foreign } \\
\text { products }\end{array}$ & $\begin{array}{l}\text { Foreign } \\
\text { products are } \\
\text { cheap }\end{array}$ & $\begin{array}{l}\text { Foreign } \\
\text { products } \\
\text { last long }\end{array}$ & $\begin{array}{l}\text { Foreign product } \\
\text { are great value }\end{array}$ & \begin{tabular}{|c|} 
Foreign \\
products low \\
qual
\end{tabular} & $\begin{array}{l}\text { Happy } \\
\text { foreign } \\
\text { products }\end{array}$ & $\begin{array}{c}\text { Recommend } \\
\text { foreign products }\end{array}$ & \begin{tabular}{|c|} 
Reject products I have \\
negative attitude \\
towards
\end{tabular} \\
\hline \multicolumn{10}{|c|}{ Gender } \\
\hline \multirow{3}{*}{ Male } & $\mathrm{N}$ & 249 & 249 & 249 & \begin{tabular}{|l|l}
249 &
\end{tabular} & 249 & 249 & 246 & 246 \\
\hline & Mean & 3,36 & 3,09 & 3,32 & 2,77 & 3,51 & 2,72 & 2,93 & 2,41 \\
\hline & \begin{tabular}{|l|}
$\mathrm{SD}$ \\
\end{tabular} & 1,288 & 1,251 & 1,164 & 1,274 & 1,248 & 1,302 & 1,187 & 1,287 \\
\hline \multirow{3}{*}{ Female } & $\mathrm{N}$ & 225 & 224 & 223 & 224 & 225 & 225 & 224 & 222 \\
\hline & Mean & 3,23 & 2,93 & 3,49 & 3,04 & 3,14 & 2,79 & 3,06 & 2,53 \\
\hline & SD & 1,202 & 1,276 & 1,193 & 1,167 & 1,193 & 1,256 & 1,164 & 1,324 \\
\hline \multirow{3}{*}{ Total } & $\mathrm{N}$ & 474 & 473 & 472 & 473 & 474 & 474 & 470 & 468 \\
\hline & Mean & 3,30 & 3,01 & 3,40 & 2,90 & 3,33 & 2,75 & 2,99 & 2,47 \\
\hline & \begin{tabular}{|l|}
$S D$ \\
\end{tabular} & 1,248 & 1,264 & 1,180 & 1,231 & 1,235 & 1,279 & 1,176 & 1,304 \\
\hline \multicolumn{10}{|c|}{ Age } \\
\hline \multirow{3}{*}{$18-20$} & $\mathrm{~N}$ & 145 & 145 & 145 & 145 & 145 & 145 & 143 & 142 \\
\hline & Mean & 3,36 & 3,01 & 3,51 & 2,74 & 3,32 & 2,66 & 2,90 & 2,63 \\
\hline & SD & 1,257 & 1,247 & 1,179 & 1,225 & 1,301 & 1,281 & 1,124 & 1,360 \\
\hline \multirow{3}{*}{$21-35$} & $\mathrm{~N}$ & 257 & 256 & 255 & 256 & 257 & 257 & 255 & 254 \\
\hline & Mean & 3,31 & 3,03 & 3,38 & 2,87 & 3,39 & 2,73 & 2,96 & 2,41 \\
\hline & SD & 1,226 & 1,298 & 1,191 & 1,226 & 1,226 & 1,294 & 1,198 & 1,294 \\
\hline \multirow{3}{*}{$36-50$} & \begin{tabular}{|l|}
$\mathrm{N}$ \\
\end{tabular} & 56 & 56 & 56 & 56 & 56 & 56 & 56 & 56 \\
\hline & Mean & 3,13 & 2,86 & 3,32 & 3,38 & 3,11 & 3,14 & 3,29 & 2,45 \\
\hline & SD & 1,280 & 1,257 & 1,162 & 1,229 & 1,171 & 1,212 & 1,232 & 1,190 \\
\hline \multirow{3}{*}{$51-65$} & $\mathrm{~N}$ & 16 & 16 & 16 & 16 & 16 & 16 & 16 & 16 \\
\hline & Mean & 3,06 & 3,25 & 2,94 & 3,19 & 3,38 & 2,63 & 3,44 & 2,00 \\
\hline & SD & 1,436 & 856 & 998 & 981 & ,957 & 1,088 & 892 & 1,265 \\
\hline \multirow{3}{*}{ Total } & $\mathrm{N}$ & 474 & 473 & 472 & 473 & 474 & 474 & 470 & 468 \\
\hline & Mean & 3,30 & 3,01 & 3,40 & 2,90 & 3,33 & 2,75 & 2,99 & 2,47 \\
\hline & \begin{tabular}{|l|}
$\mathrm{SD}$ \\
\end{tabular} & 1,248 & 1,264 & 1,180 & 1,231 & 1,235 & 1,279 & 1,176 & 1,304 \\
\hline \multicolumn{10}{|c|}{ Level Of Education } \\
\hline \multirow{3}{*}{ Primary } & $\mathrm{N}$ & 3 & 3 & 3 & \begin{tabular}{l|l}
3 \\
\end{tabular} & 3 & 3 & 3 & 3 \\
\hline & Mean & 3,00 & 3,00 & 3,00 & 2,00 & 3,33 & 3,33 & 3,67 & 2,67 \\
\hline & \begin{tabular}{|l|} 
SD \\
\end{tabular} & 1,000 & 2,000 & 0,000 & 1,000 & 1,528 & 1,155 &, 577 &, 577 \\
\hline \multirow{3}{*}{ High School } & $\mathrm{N}$ & 220 & 220 & 218 & 219 & 220 & 220 & 217 & 216 \\
\hline & Mean & 3,37 & 3,05 & 3,52 & 2,79 & 3,35 & 2,77 & 2,90 & 2,58 \\
\hline & SD & 1,223 & 1,288 & 1,169 & 1,267 & 1,307 & 1,322 & 1,180 & 1,330 \\
\hline & \begin{tabular}{|l|}
$\mathrm{N}$ \\
\end{tabular} & 85 & 85 & 85 & 85 & 85 & 85 & 85 & 84 \\
\hline Diploma & Mean & 3,20 & 2,98 & 3,44 & 3,00 & 3,28 & 2,84 & 2,89 & 2,33 \\
\hline & \begin{tabular}{|l|}
$\mathrm{SD}$ \\
\end{tabular} & 1,261 & 1,371 & 1,200 & 1,205 & 1,287 & 1,370 & 1,205 & 1,311 \\
\hline & $\mathrm{N}$ & 110 & 109 & 110 & 110 & 110 & 110 & 109 & 109 \\
\hline Degree & Mean & 3,32 & 3,02 & 3,32 & 2,97 & 3,30 & 2,82 & 3,15 & 2,50 \\
\hline & \begin{tabular}{|l|}
$S D$ \\
\end{tabular} & 1,292 & 1,170 & 1,203 & 1,237 & 1,185 & 1,235 & 1,145 & 1,288 \\
\hline & $\mathrm{N}$ & 56 & 56 & 56 & 56 & 56 & 56 & 56 & 56 \\
\hline Postgraduate & Mean & 3,11 & 2,89 & 3,07 & 3,05 & 3,39 & 2,39 & 3,16 & 2,16 \\
\hline & \begin{tabular}{|l|}
$\mathrm{SD}$ \\
\end{tabular} & 1,260 & 1,171 & 1,126 & 1,102 & 947 & 1,003 & 1,172 & 1,218 \\
\hline & $\mathrm{N}$ & 474 & 473 & 472 & 473 & 474 & 474 & 470 & 468 \\
\hline Total & Mean & 3,30 & 3,01 & 3,40 & 2,90 & 3,33 & 2,75 & 2,99 & 2,47 \\
\hline & \begin{tabular}{|l|} 
SD \\
\end{tabular} & 1,248 & 1,264 & 1,180 & \begin{tabular}{l|l}
1,231 \\
\end{tabular} & 1,235 & 1,279 & 1,176 & 1,304 \\
\hline & & & & & Ethnicity & & & & \\
\hline & $\mathrm{N}$ & 312 & 311 & 311 & 311 & 312 & 312 & 308 & 306 \\
\hline Black & Mean & 3,21 & 2,96 & 3,40 & 2,99 & 3,29 & 2,95 & 3,11 & 2,45 \\
\hline & \begin{tabular}{|l|} 
SD \\
\end{tabular} & 1,260 & 1,303 & 1,200 & 1,290 & 1,298 & 1,320 & 1,227 & 1,318 \\
\hline & \begin{tabular}{|l|}
$\mathrm{N}$ \\
\end{tabular} & 50 & 50 & 49 & 50 & 50 & 50 & 50 & 50 \\
\hline White & Mean & 3,46 & 3,18 & 3,29 & 2,82 & 3,36 & 2,52 & 3,02 & 2,26 \\
\hline & \begin{tabular}{|l|}
$\mathrm{SD}$ \\
\end{tabular} & 1,216 & 1,024 & ,935 & 1,004 & 964 & 1,165 & 937 & 1,175 \\
\hline & $\mathrm{N}$ & 54 & 54 & 54 & 54 & 54 & 54 & 54 & 54 \\
\hline Coloured & Mean & 3,56 & 2,98 & 3,56 & 2,65 & 3,37 & 2,48 & 2,81 & 2,74 \\
\hline & \begin{tabular}{|l|} 
SD \\
\end{tabular} & 1,160 & 1,141 & 1,144 & 1,102 & 1,033 & 1,005 & ,973 & 1,262 \\
\hline & $\mathrm{N}$ & 58 & 58 & 58 & 58 & 58 & 58 & 58 & 58 \\
\hline Indian & Mean & 3,38 & 3,19 & 3,38 & 2,72 & 3,53 & 2,14 & 2,52 & 2,52 \\
\hline & \begin{tabular}{|l|} 
SD \\
\end{tabular} & 1,268 & 1,344 & 1,295 & 1,167 & 1,273 & 1,115 & 1,143 & 1,367 \\
\hline & $\mathrm{N}$ & 474 & 473 & 472 & 473 & 474 & 474 & 470 & 468 \\
\hline Total & Mean & 3,30 & 3,01 & 3,40 & 2,90 & 3,33 & 2,75 & 2,99 & 2,47 \\
\hline & \begin{tabular}{|l|}
$S D$ \\
\end{tabular} & 1,248 & 1,264 & 1,180 & 1,231 & 1,235 & 1,279 & 1,176 & 1,304 \\
\hline
\end{tabular}

